X. DAI, S. ADOMEIT, J. RABEAH, C. KREYENSCHULTE, A. BRÜCKNER*, H. WANG, F. SHI* (LANZHOU INSTITUTE OF CHEMICAL PHYSICS AND UNIVERSITY OF CHINESE ACADEMY OF SCIENCES, BEIJING, P. R. OF CHINA; LEIBNIZ-INSTITUT FÜR KATALYSE E.V. AN DER UNIVERSITÄT ROSTOCK ( LIKAT), GERMANY)

Sustainable Co-Synthesis of Glycolic Acid, Formamides and Formates from 1,3-Dihydroxyacetone by a Cu/ $\mathrm{Al}_{2} \mathrm{O}_{3} \mathrm{Catalyst}$ with a Single Active Sites

Angew. Chem. Int. Ed. 2019, 58, 5251-5255.

\section{Co-Synthesis of Glycolic Acids, Formamides, and Formates on Copper/Alumina}

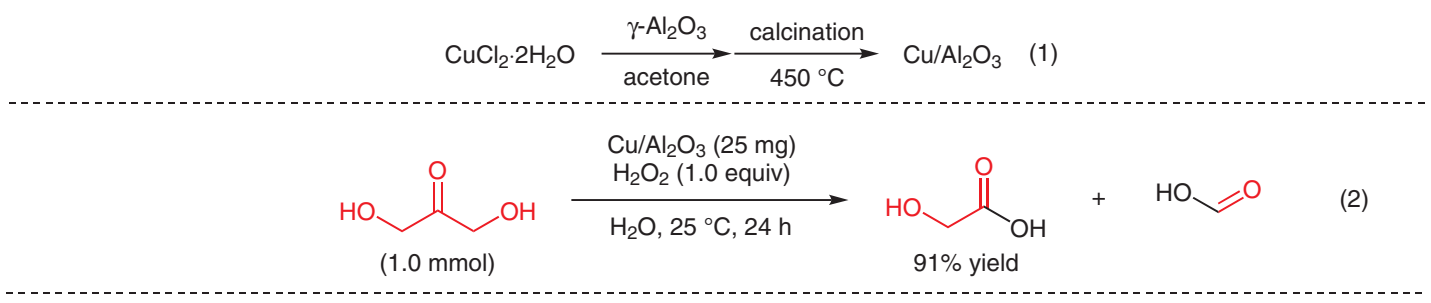

\section{Category}

Polymer-Supported Synthesis

\section{Key words}

copper catalysis

formates

dihydroxyacetone

glycolic acid

formylation

formamides
Significance: An alumina-supported copper catalyst $\left(\mathrm{Cu} / \mathrm{Al}_{2} \mathrm{O}_{3}\right)$ was prepared by mixing copper(II) chloride with alumina, followed by calcination (eq. 1). $\mathrm{Cu} / \mathrm{Al}_{2} \mathrm{O}_{3}$ catalyzed the oxidative degradation of 1,3-dihydroxyacetone with hydrogen peroxide in water to give glycolic acid in $91 \%$ yield with co-production of formic acid (eq. 2). The reaction also proceeded in the presence of amines or alcohols to afford the corresponding formamides or formates as co-products in 70-99\% yield (eq. 3).

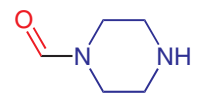

$84 \%$ yield<smiles>O=CNc1ccc(Cl)cc1</smiles>

$90 \%$ yield<smiles>COc1ccccc1COC=O</smiles>

$70 \%$ yield

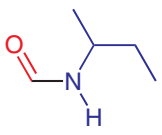

$99 \%$ yield<smiles>CN(C=O)c1ccccc1</smiles>

$95 \%$ yield<smiles>O=COCc1ccc(Br)cc1</smiles>

$80 \%$ yield
Comment: In the oxidation of 1,3-dihydroxyacetone, $\mathrm{Cu} / \mathrm{Al}_{2} \mathrm{O}_{3}$ was recovered by centrifugation and reused twice without loss of its catalytic performance (fresh: $91 \%$ yield; third run: $88 \%$ ). ICP analyses and a filtration test suggested that the reaction proceeds heterogeneously. XRD, HAADFSTEM, and $\mathrm{N}_{2}$ adsorption-desorption experiments on the reused catalyst showed no obvious changes in its structure. 